\title{
Innovation Ecosystem Research: Emerging Trends and Future Research
}

\author{
Yanzhang $\mathrm{Gu}^{1}{ }^{1} *$, Longying $\mathrm{Hu}^{1}{ }^{1}$, Hongjin Zhang ${ }^{1}$ and Chenxuan Hou ${ }^{2}$ \\ 1 School of Management, Harbin Institute of Technology, Harbin 150001, China; huly@hit.edu.cn (L.H.); \\ hongjinzhanghit@163.com (H.Z.) \\ 2 School of Management, Zhejiang University of Technology, Hangzhou 310023, China; houchenxuan@126.com \\ * Correspondence: guyanzhang123@163.com
}

Citation: Gu, Y.; Hu, L.; Zhang, H.;

Hou, C. Innovation Ecosystem

Research: Emerging Trends and

Future Research. Sustainability 2021,

13, 11458. https://doi.org/10.3390/ su132011458

Academic Editor: Jasmin

Mantilla-Contreras

Received: 31 July 2021

Accepted: 12 October 2021

Published: 16 October 2021

Publisher's Note: MDPI stays neutral with regard to jurisdictional claims in published maps and institutional affiliations.

Copyright: (c) 2021 by the authors. Licensee MDPI, Basel, Switzerland. This article is an open access article distributed under the terms and conditions of the Creative Commons Attribution (CC BY) license (https:// creativecommons.org/licenses/by/ $4.0 /)$.

\begin{abstract}
The innovation ecosystem term has increasingly been attracting the interest of scholars and practitioners for fifteen years. Contrary to the flourishing landscape, knowledge in this field is criticized as being fragmented. While past reviews revealed the conceptual and theoretical connections between innovation ecosystem and other related concepts, there is still a lack of comprehensive appreciation of the intellectual structure of state-of-the-art innovation ecosystem studies, hindering future research in this domain. To fill this void, this study utilized a systematic literature review approach combining bibliographic coupling and content analysis methods. Drawing on 136 studies reflecting the core and latest knowledge of innovation ecosystem literature, this study identifies five streams of the current innovation ecosystem research (i.e., technology innovation, platform innovation ecosystem, regional development, innovation ecosystem conceptualization and theorization, and entrepreneurship and innovation). Suggestions for future research are distilled via systematic analysis and discussion of these streams. Contributions of this study lie in decoding the intellectual structure of current innovation ecosystem research and offering targeted recommendations for future research.
\end{abstract}

Keywords: innovation ecosystem; sustainable innovation; systematic literature review; platformization and digitalization; regional development; entrepreneurial innovation

\section{Introduction}

In the past fifteen years, literature on innovation ecosystem (IE) experienced exponential growth, especially the boom in the recent three years when more than half of the IE studies were published. IE has been increasingly gaining significant and widespread academic attention in multiple fields, including innovation [1,2], business [3,4], economic [5,6], and sustainability [7-9]. Taking the research on sustainability as an example, IE has been utilized to explore diverse sustainable issues, including green product production [10-12], sustainable enterprise development [13,14], circular industrial economies [15-17], and sustainable regional transformations $[7,18,19]$. This indicates that IE as an effective approach has played a significant role in advancing sustainability in recent years. Contrary to its popularity in academia, IE was found to be loosely mentioned and discussed under various backgrounds [20-22], leading to heterogeneous and inconsistent IE connotations in the literature [23-25]. Extant IE literature is regarded as fragmented, lacking comprehensive appreciation $[20,25,26]$.

This scenario has promoted several literature reviews on IE in recent years, mainly decoding the IE concept and research themes [22,23,27,28], or primarily differentiating IE from other interrelated concepts and clustering studies in these cross-connected domains $[6,20,26]$. As one of the key types of ecosystems, IE has also been reviewed by prior reviews classifying ecosystem concepts and studies [3,24,25,29-32]. These reviews mainly contributed to the conceptualization of IE, distinguishing IE from other related concepts, and classifying and comparing the sub-fields of ecosystem research. While they confirm 
that IE research has been established as one domain distinct from others such as innovation system and business ecosystem, they fall short in decoding the research fronts of the IE literature and distilling targeted implications for future IE studies. To fill the gap, the current review unfolds to focus closely on IE studies, unpack the intellectual structure of state-of-the-art IE studies, and propose targeted pathways for future IE studies.

To this end, this study utilized a systematic literature review approach that combines a bibliographic coupling technique and content analysis method. Specifically, it may contribute to the IE literature mainly in three ways. First, it centers on IE and includes the latest updated IE studies to achieve more targeted and comprehensive findings and implications for IE research. This is mainly due to the considerations that prior IE literature has proposed an explicit and universal IE definition [23] and validated the differences between IE and other relevant concepts $[27,30,31]$, that excluding other interrelated concepts helps to reduce noise knowledge from those fields, and that the newly published IE studies in recent years are far more than those that have been reviewed. Second, this study complements existing reviews by revealing the complex intellectual structure of the core part of IE studies that is most reflective of the common knowledge and emerging research trends of extant IE studies. Finally, the identified research suggestions distilled from the respective research streams may contribute to IE literature by inspiring future research. In sum, this review differs from previous reviews due to its distinct investigated IE literature, the different research aims, and the complementary findings focusing on IE.

Following this section, Section 2 presents past literature reviews on IE. Section 3 displays the research method, followed by Section 4 presenting the main results. Section 5 discusses the results to produce suggestions for future IE research. At the end are the conclusions.

\section{Literature Review}

\subsection{IE Definitions}

Explicitly defining IE is one of the prerequisites to comprehensively appreciate this emerging field. Twenty-two explicit IE definitions were generated by past IE studies (Table A1, Appendix A). From a longitudinal view, these IE definitions have been increasingly comprehensive and compatible. Specifically, from 2006 to 2009, IE was seen as "arrangements" in industry chains [33] or "processes" in innovation clusters [34]. Then, a network view was utilized to define the IE concept in the period from 2013 to 2017. For instance, IE was regarded as "a loosely interconnected network" [35]. From 2018 to date, both the system view and network view have been adopted to define the IE concept. As defined recently, IE refers to a "system" [36], "network" [37], or "network system" [10]. Besides, methods to generate IE definitions tend to be more complex and systematic, shifting from citing related studies [35] in the early phase to systematic literature reviews [23] in recent years, which contributes to the robustness of IE definitions.

From a horizontal view, following Granstrand and Holgersson [23], five classes of keywords consisting of actors, activities, relations, artifacts, and evolution were found from the 22 influential and widely used definitions of IE (Table A1, Appendix A). To be specific, actors (e.g., organizations, suppliers, customers, and governments) and activities (e.g., develop products and services, promote innovation, and create and capture value) were included in all these IE definitions. However, relations (e.g., collaborative, cooperative, competitive, and symbiotic) and artifacts (e.g., offerings, resources, technologies, and information) were missed in 2 of these 22 IE definitions. evolution (e.g., dynamic, evolutionary, coevolve, and lifecycle) was ignored in 6 of these 22 IE definitions. In sum, these keywords present a complete set of components that were agreed upon by most scholars in defining IE. These five classes of keywords were employed as a conceptual framework of IE in the discussion and future research section of this study.

\subsection{IE-Related Reviews}

Some reviews contributed to conceptualizing IE. For instance, Oh et al. [22] argued that the loosely defined IE concept in past literature might bring more risks than benefits. 
Gomes et al. [27] reviewed the research on IE and business ecosystem between 1993 and 2016 and concluded that IE relates more to value creation while business ecosystem relates more to value capture. Tomas et al. [28] illustrated three ways to categorize IE structure (i.e., ecosystem life cycle, ecosystem levels, and ecosystem layers). Granstrand and Holgersson [23] synthesized diverse IE definitions into a more compatible one by integrating structural ecosystem elements, including actors, activities, artifacts, and institutions.

Meanwhile, IE is rooted in other maturing research fields such as innovation network and innovation system $[6,26]$. Hence, past reviews also examined the connections between IE and those established concepts. For example, Russo-Spena et al. [26] identified five shared topics among three streams of innovation research (i.e., system, network, and ecosystem) and revealed the research commonalities and differences among them. Bassis and Armellini [6] argued that IE and innovation systems complement each other and found that they share three elements (i.e., innovation perception, agents' role, and interaction and network). Suominen et al. [20] compared the research streams and theoretical foundations of innovation systems and ecosystem studies, respectively.

In addition, other literature reviews compared the research on IE and other concepts under the umbrella concept ecosystem. For instance, Jacobides et al. [30] and Shipilov and Gawer [31] divided ecosystem research in the management field into three streams (i.e., IE, business ecosystem, and platform ecosystem), and compared the differences among them. Gupta et al. [24] found that the IE area shares few studies with business ecosystem and digital ecosystem domains. Hakala et al. [29] argued that IE, business ecosystem, and entrepreneurial ecosystem respectively focus on the dynamic of interaction, the quantity of interaction, and regional development. Aarikka-Stenroos and Ritala [3] highlighted that notwithstanding the fact that IE and other sub-concepts of ecosystem involve different themes and assumptions, ecosystem as a broader perspective may serve as a promising layer or perspective to advance B2B (business to business) network research. Thomas and Autio [25] found that the confusing ecosystem concepts and applications in management literature mainly result from different types of unit of analysis and ecosystem output, according to which ecosystems can be divided into IE (business ecosystem, modular ecosystem, and platform ecosystem), entrepreneurial ecosystem, and knowledge ecosystem.

These IE-related reviews not only enhanced the conceptual understanding of IE by revealing its commonalities and differences with other similar concepts, but also demonstrated the research situations where IE and these concepts appear in different periods (see Table 1). However, the literature shows a lack of revealing the intellectual structure of IE research front to offer recommendations for future research. This is more urgent considering the fragmented landscape of this field combined with the proliferation of published IE papers in the recent three years beyond the timespan of prior reviews. Besides, recent studies have provided a reasonable conceptual and theoretical basis to screen IE from other analogous concepts to generate more targeted findings to promote IE research $[23,25,29,30,38]$. Therefore, drawing on existing methodological and theme-relevant studies, this study aims to smooth the gap by a systematic literature review approach detailed in the next section.

Table 1. Representative IE-related reviews.

\begin{tabular}{|c|c|c|c|c|}
\hline Authors, Year & $\begin{array}{l}\text { Themes (Number } \\
\text { of Documents) }\end{array}$ & Period & Methods & Summary \\
\hline Oh et al., 2016 [22] & IE (undefined) & Undefined & $\begin{array}{l}\text { Conceptual and } \\
\text { theoretical }\end{array}$ & $\begin{array}{l}\text { - A critical review of the IE term. } \\
\text { The ambiguous usage of the IE term is not more } \\
\text { beneficial than national and regional IS. }\end{array}$ \\
\hline
\end{tabular}


Table 1. Cont.

\begin{tabular}{|c|c|c|c|c|}
\hline Authors, Year & $\begin{array}{l}\text { Themes (Number } \\
\text { of Documents) }\end{array}$ & Period & Methods & Summary \\
\hline $\begin{array}{l}\text { Dedehayir et al., } \\
\quad 2018[21]\end{array}$ & IE (60) & 1996-2015 & Content analysis & $\begin{array}{l}\text { - Discern four sets of roles that characterize actors' } \\
\text { behaviors and activities across three stages of IE } \\
\text { birth. }\end{array}$ \\
\hline $\begin{array}{l}\text { Gomes et al., } \\
2018 \text { [27] }\end{array}$ & IE, BE (125) & 1993-2016 & $\begin{array}{l}\text { Bibliometric and } \\
\text { content analysis }\end{array}$ & $\begin{array}{l}\text { - Identify a transition from BE mainly focusing on } \\
\text { value capture to IE mainly focusing on value } \\
\text { creation in the literature. } \\
\text { Summarize six streams of IE research and propose } \\
\text { corresponding research opportunities. }\end{array}$ \\
\hline $\begin{array}{l}\text { Granstrand and } \\
\text { Holgersson, } \\
2020 \text { [23] }\end{array}$ & IE (21) & 2006-2018 & Content analysis & $\begin{array}{l}\text { - } \quad \text { Define IE based on synthesizing the elements of } \\
21 \text { IE definitions in previous IE literature. } \\
\text { - Validate this IE definition by three cases. }\end{array}$ \\
\hline $\begin{array}{l}\text { Tomas et al., } \\
2020[28]\end{array}$ & IE, BE (61) & 1993-2019 & $\begin{array}{l}\text { Bibliometric and } \\
\text { content analysis }\end{array}$ & $\begin{array}{l}\text { Identify and analyze three approaches to define IE } \\
\text { structure, namely ecosystem life cycle, ecosystem } \\
\text { level, and layered structure. }\end{array}$ \\
\hline $\begin{array}{l}\text { Russo-Spena et al., } \\
2017 \text { [26] }\end{array}$ & $\begin{array}{l}\text { IS (1833), IN (444), } \\
\text { IE (227) }\end{array}$ & 1985-2015 & Content analysis & $\begin{array}{l}\text { - Identify and compare five shared thematic elements } \\
\text { in IS, IN, and IE domains. } \\
\text { Elaborate how the SE approach can advance service } \\
\text { innovation research. }\end{array}$ \\
\hline $\begin{array}{l}\text { Zhang and Guan, } \\
\text { 2017 [39] }\end{array}$ & $\begin{array}{l}\text { IE, EE, BE, PE, etc. } \\
\text { (314) }\end{array}$ & 1996-2016 & $\begin{array}{l}\text { Co-citation and } \\
\text { network } \\
\text { meta-analysis }\end{array}$ & $\begin{array}{l}\text { - Define IEE that emphasizes network openness, } \\
\text { organization symbiosis, and actor interdependence. } \\
\text { Analyze IEE research metaknowledge in terms of } \\
\text { trends and features using a novel method. }\end{array}$ \\
\hline $\begin{array}{l}\text { Amitrano et al., } \\
2018[40]\end{array}$ & IS (334), IE (92) & 2006-2017 & Content analysis & $\begin{array}{l}\text { - Identify seven mutual topics reflecting the roles of } \\
\text { technology in IS and IE literature. }\end{array}$ \\
\hline $\begin{array}{c}\text { Bassis and } \\
\text { Armellini, } 2018[6]\end{array}$ & $\begin{array}{l}\text { IE, BE, IS } \\
\text { (undefined) }\end{array}$ & Undefined & Content analysis & $\begin{array}{l}\text { - Compare the concepts, literature, and framework of } \\
\text { IS and IE theories. } \\
\text { The two theories complement each other in terms of } \\
\text { actors' interactions, evolutionary theories, and } \\
\text { building elements. }\end{array}$ \\
\hline $\begin{array}{l}\text { Suominen et al., } \\
2019[20]\end{array}$ & $\begin{array}{l}\text { IS, BS, BE, IE (3652); } \\
\text { BE, IE (329) }\end{array}$ & 1990-2015 & $\begin{array}{l}\text { Bibliographical } \\
\text { coupling and } \\
\text { co-citation analysis }\end{array}$ & $\begin{array}{l}\text { - Explore six research streams and five clusters of } \\
\text { theoretical foundations of IS and ecosystem } \\
\text { literature. } \\
\text { Identify seven research streams and five groups of } \\
\text { theoretical bases of ecosystem literature. }\end{array}$ \\
\hline $\begin{array}{l}\text { Aarikka-Stenroos } \\
\text { and Ritala, } 2017 \text { [3] }\end{array}$ & Ecosystem (71) & 1999-2016 & Content analysis & $\begin{array}{l}\text { - Categorize four ecosystem approaches in B2B } \\
\text { literature. } \\
\text { Ecosystem-as-layer and ecosystem-as-perspective } \\
\text { may revise extant B2B network research framework. }\end{array}$ \\
\hline $\begin{array}{l}\text { Jacobides et al., } \\
2018[30]\end{array}$ & $\begin{array}{l}\text { Ecosystem } \\
\text { (undefined) }\end{array}$ & Undefined & $\begin{array}{l}\text { Conceptual and } \\
\text { theoretical }\end{array}$ & $\begin{array}{l}\text { - Propose an ecosystem definition by leveraging } \\
\text { complementarity and modularity. } \\
\text { Divide ecosystem literature in management domain } \\
\text { into three clusters, namely BE, IE, and PE. }\end{array}$ \\
\hline $\begin{array}{l}\text { Tsujimoto et al., } \\
2018[32]\end{array}$ & Ecosystem (90) & 1995-2014 & Content analysis & $\begin{array}{l}\text { - Analyze ecosystem concept in technology and } \\
\text { innovation management literature. } \\
\text { - Identify four research streams of ecosystem research } \\
\text { contributing to an integrated model. } \\
\text { Define ecosystem and propose a coherency concept } \\
\text { helpful to explain ecosystem evolution. }\end{array}$ \\
\hline $\begin{array}{l}\text { Gupta et al., } \\
2019[24]\end{array}$ & $\begin{array}{l}\text { BE (545), IE (150), } \\
\text { DE (406) }\end{array}$ & Undefined & $\begin{array}{l}\text { Keywords network } \\
\text { analysis }\end{array}$ & $\begin{array}{l}\text { - Map the sharing and distinct terminologies in BE, } \\
\text { IE, and DE fields. } \\
\text { Illustrate three keywords covering BE-IE-DE, } \\
\text { BE-DE, and IE literature, respectively. }\end{array}$ \\
\hline $\begin{array}{l}\text { Hakala et al., } \\
2020[29]\end{array}$ & BE, EE, IE (55) & 1993-2018 & Content analysis & $\begin{array}{l}\text { - Propose a novel method for reviewing the dominant } \\
\text { narratives in a given field. } \\
\text { Employ this method to compare the themes and } \\
\text { theoretical puzzles, construction of ecosystem } \\
\text { stories, and relevance of ecosystem studies in BE, } \\
\text { EE, and IE fields. }\end{array}$ \\
\hline
\end{tabular}


Table 1. Cont.

\begin{tabular}{|c|c|c|c|c|}
\hline Authors, Year & $\begin{array}{l}\text { Themes (Number } \\
\text { of Documents) }\end{array}$ & Period & Methods & Summary \\
\hline $\begin{array}{l}\text { Shipilov and Gawer, } \\
2020[31]\end{array}$ & $\begin{array}{l}\text { Ecosystem, network } \\
\quad \text { (undefined) }\end{array}$ & Undefined & $\begin{array}{l}\text { Conceptual and } \\
\text { theoretical }\end{array}$ & $\begin{array}{l}\text { - Partially integrate two streams of literature } \\
\text { (i.e., networks and ecosystems) to advance each } \\
\text { other. } \\
\text { Divide ecosystem studies in management field into } \\
\text { three streams (i.e., BE, IE, and PE). }\end{array}$ \\
\hline $\begin{array}{c}\text { Thomas and Autio, } \\
2020[25]\end{array}$ & $\begin{array}{l}\text { Ecosystem } \\
\text { (undefined) }\end{array}$ & Undefined & $\begin{array}{l}\text { Conceptual and } \\
\text { theoretical }\end{array}$ & $\begin{array}{l}\text { - Conceptual heterogeneity of the ecosystem } \\
\text { constructs mainly results from the differences in } \\
\text { terms of the unit of analysis and ecosystem outputs. } \\
\text { Categorize ecosystem concepts in management } \\
\text { literature into IE (involving BE, ME, PE), EE, and } \\
\text { KE. }\end{array}$ \\
\hline Wang, 2021 [41] & $\begin{array}{l}\text { Ecosystem } \\
\text { (undefined) }\end{array}$ & Undefined & $\begin{array}{l}\text { Conceptual and } \\
\text { theoretical }\end{array}$ & $\begin{array}{l}\text { - Identify and classify six types of ecosystem concepts } \\
\text { from information system and organization studies } \\
\text { fields into four levels of analysis. } \\
\text { Propose a digital IE definition and "Information } \\
\text { Ecology Theory" to address part-whole relations by } \\
\text { integrating digital innovations with ecosystems } \\
\text { literature. }\end{array}$ \\
\hline
\end{tabular}

Note: IE (innovation ecosystem), IS (innovation system), IN (innovation network), SE (service ecosystem), EE (entrepreneurial ecosystem), BE (business ecosystem), PE (platform ecosystem), DE (digital ecosystem), BS (business system), IEE (innovation and entrepreneurial ecosystem), KE (knowledge ecosystem), and ME (modular ecosystem).

\section{Method}

This study utilized a systematic literature review method following prior review studies [42,43]. Specifically, Science Citation Index Expanded (SCIE) and Social Sciences Citation Index (SSCI) databases were selected to identify IE studies because they provide wide studies with high academic influence as well as complete bibliometric metadata for each document $[24,26,28]$. Drawing on previous reviews [23,24], documents were retrieved in January 2021 by an exact search query of "innovation ecosystem *" in the Topic field that covers the content of Title, Abstract, Author Keywords, and KeyWords Plus ${ }^{\circledR}$ of each paper. Limiting document type to English Article or Review, consistent with past IE review [27], resulted in 428 documents published in the past fifteen years. Further, the title, keywords, abstract, and main body of each article were analyzed, excluding 23 studies not relevant to IE. Finally, 405 articles produced by 174 journals between 2006 and 2020 served as the literature pool to identify core IE studies.

To unpack the structure of IE research front, a hybrid methodology combining the bibliographic coupling technique with the content analysis method was employed in line with prior works $[20,43]$. On the one hand, the bibliographic coupling technique is among the most suitable methods for evaluating state-of-the-art research in a given domain $[43,44]$. On the other hand, the content analysis method allows improving the analysis according to the main content of each document rather than the objective citation relationships considering the ambiguities of IE concept and literature [20,23]. The specific steps and tools are as follows: VOSviewer 1.6.10 software [45] was utilized to generate bibliographic coupling network files based on the bibliometric metadata of the 405 IE publications. Then, these files were imported into Pajek64 5.13 software [46] to extract the bibliographic coupling matrix. The matrix was reduced using Excel by only including the documents that rank in the top 30\% in reflecting the common knowledge of IE research according to two indicators, namely the tie strength (indicating the total frequencies of shared references of a given document with other documents) and node degree (representing the number of documents sharing references with a given document) of each document in the bibliometric coupling matrix. Since there was a large overlap of the results for the two indicators, 136 studies (tie strength ranging from 384 to 1529, node degree ranging from 181 to 275) from 58 journals between 2009 and 2020 were selected as the core IE studies reflecting the research fronts. We analyzed the contents of the research questions, aims, and objects of these articles to identify their research focuses. Based on this, the 136 IE studies were 
grouped into five research streams, each of which mainly reflecting a research focus shared by the IE studies in this research stream.

\section{Results}

\subsection{Descriptive Analysis}

Figure 1 shows the distribution of the extracted IE articles and identified core IE articles. Most of the articles in both groups were published in the recent five years with rapid growth. Table 2 presents the 36 main source journals that published about $50 \%$ of the IE articles and $80 \%$ of the core IE articles. Sustainability ranks as the first and second journal in the two lists, contributing 42 IE articles and 14 core IE articles, respectively.

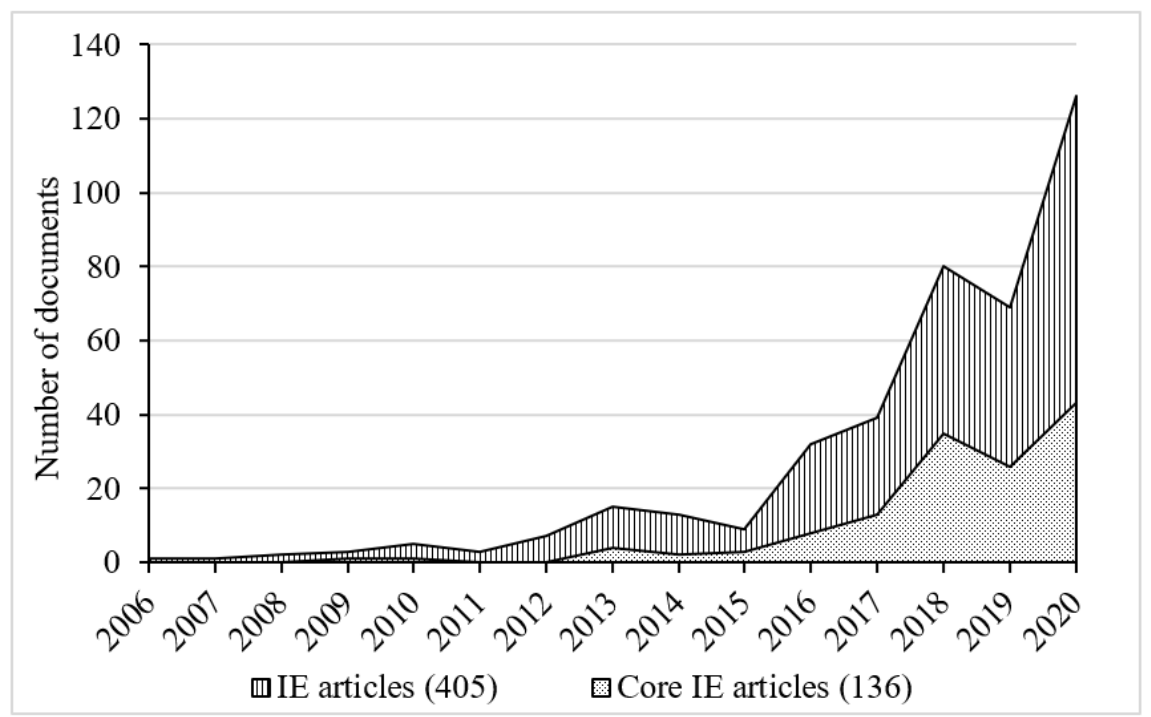

Figure 1. Published articles in IE field from 2006 to 2020.

Table 2. Source journals of IE research.

\begin{tabular}{ccc}
\hline Representative Journals & $\begin{array}{c}\text { Number of } \\
\text { IE Articles }\end{array}$ & $\begin{array}{c}\text { Number of Core } \\
\text { IE Articles }\end{array}$ \\
\hline Academy of Management Annals & 2 & 2 \\
Academy of Management Journal & 1 & 1 \\
Academy of Management Review & 2 & 1 \\
Administrative Science Quarterly & 1 & 1 \\
Business \& Society & 2 & 1 \\
California Management Review & 4 & 2 \\
Computers in Human Behavior & 1 & 1 \\
Energy Policy & 1 & 1 \\
Entrepreneurship Theory and Practice & 1 & 1 \\
European Journal of Innovation Management & 12 & 5 \\
European Management Review & 1 & 1 \\
Industrial Marketing Management & 1 & 1 \\
Industry and Innovation & 3 & 2 \\
International Journal of Information Management & 2 & 1 \\
International Journal of Management Reviews & 1 & 1 \\
International Journal of Production Economics & 4 & 3 \\
International Journal of Technology Management & 11 & 8 \\
Journal of Business Research & 3 & 2 \\
Journal of Cleaner Production & 8 & 5 \\
Journal of International Business Studies & 2 & 2 \\
\hline
\end{tabular}


Table 2. Cont.

\begin{tabular}{ccc}
\hline Representative Journals & $\begin{array}{c}\text { Number of } \\
\text { IE Articles }\end{array}$ & $\begin{array}{c}\text { Number of Core } \\
\text { IE Articles }\end{array}$ \\
\hline Journal of Management & 1 & 1 \\
Journal of Management Studies & 1 & 1 \\
Journal of Strategic Information Systems & 2 & 1 \\
Long Range Planning & 3 & 3 \\
Management Decision & 4 & 2 \\
Management Science & 2 & 1 \\
Organization Science & 2 & 2 \\
R \& D Management & 3 & 1 \\
Research Policy & 7 & 4 \\
Scientometrics & 4 & 2 \\
Small Business Economics & 6 & 3 \\
Strategic Entrepreneurship Journal & 1 & 1 \\
Strategic Management Journal & 9 & 8 \\
Sustainability & 42 & 14 \\
Technological Forecasting and Social Change & 40 & 24 \\
Technovation & 6 & 3 \\
Others (journals) & $209(138)$ & $23(22)$ \\
Total (journals) & $405(174)$ & $136(58)$ \\
\hline
\end{tabular}

Table 3 summarizes the methods utilized by the 136 core IE articles. Similar to prior findings, case studies and conceptual and theoretical studies are still two of the dominant methods, while different findings are that literature review has become a new main method and fuzzy set qualitative comparative analysis has emerged as a new method [27]. This highlights that quantitative studies are still needed to consolidate existing qualitative, conceptual, and context-specific findings on IE.

Table 3. Research methods of the core IE studies.

\begin{tabular}{ccc}
\hline Research Method & Number & $\%$ \\
\hline Case study & 78 & 57.35 \\
Literature review & 20 & 14.71 \\
Conceptual-theoretical & 18 & 13.24 \\
Survey & 11 & 8.09 \\
Modeling-simulation & 6 & 4.41 \\
Fuzzy set qualitative comparative analysis & 2 & 1.47 \\
Experimental & 1 & 0.74 \\
\hline
\end{tabular}

\subsection{Analysis of Identified Research Streams}

\subsubsection{Stream 1: Technology Innovation}

Articles in this stream mainly focus on issues related to how to implement technology innovation by leveraging IE. Some studies investigated the key channels to establish IE for technological innovation. Results show that cooperating with external actors for external complementary innovation resources contributes to cultivating a nascent IE [1,47], which requires the focal firm to coordinate its internal sub-organizations and external IE actors [48]. The focal firm also needs to position itself in IE according to the policy environments of different regions [49]. In this process full of uncertainties and complexities, system building strategies coping with complementarity, complexity, and timing issues [50], dynamic control via coupled feedback loops [51], experiments generating complete prototypes of technological solutions [52], and joint knowledge search integrating knowledge producers and users [53] have been found helpful in the establishment of technological IE. 
More broadly, some articles explore the life cycle of technological IE. Playing distinct roles at different phases, value creation and capture mechanisms advance the evolution of IE $[54,55]$. Research also revealed that IE architecture or structure is featured in the interactions among IE actors at the system level $[56,57]$ and managerial cognitive capability and dynamic capacities of focal firms at the actor level [13,58]; both are main drivers of IE evolution. Besides, sustainability is one of the key issues for the evolution of technological IE. To improve the sustainability of technological innovation, scholars highlighted the roles of complementary technological resources and dynamic demands and policies $[59,60]$.

To orchestrate dynamic technological IE, studies highlighted the roles of selective knowledge revealed in governing collaborations between focal firms and their IE partners [61], and patent licensing from the focal firm to SMEs (small- and medium-sized enterprises) in improving IE stability [62]. Scholars argued that effective control of knowledge transfer in IE depends on comprehensive consideration of the features of knowledge, relationship, and organization [63].

Regarding the specific impacts of inter-organizational collaborations on innovation in IE, evidence shows that collaborating with IE partners helps to increase innovation inputs and outputs [64], but contradictions arising from interactions between actors may hinder innovation [65]. Some characteristics of interdependent relationships between focal firms and their IE partners have been found to be closely related to the outcomes of innovation, including locations and strengths $[66,67]$ and distribution [68]. Research also revealed that product innovation always depends on the appropriate combinations of different kinds of inter-organizational cooperation rather than a single collaborating mode [4].

Technology as one of the key artifacts of IE always evolves. Studies illustrated that the transitions from incumbent to new technologies depend on the challenges confronting the emergence of new technologies and the opportunities supporting the extension of old technologies [69], and the cooperative and competitive relationships between IE actors, assets, and technologies, respectively [36]. Besides, technologies may act as IE environments to influence organizational technology innovation. For instance, Gao et al. [70] decoded how the focal firm responds to external technological changes by leveraging complementary partners and their technologies. Eggers and Park [71] highlighted that IE environment is one of the important antecedents of incumbent firms to adapt to technological changes.

\subsubsection{Stream 2: Platform IE}

Studies in Stream 2 emphasize how to organize platform IE, and how to develop platform technologies and products in IE. For the former, scholars mainly center on the structural configurations of platforms from an IE perspective. Gawer [72] conceptually defined platforms (firm, supply chain, and industry platforms) as "evolving organizations or meta-organizations" with modular and core-periphery structure characteristics. Leader organizations at the core of IE need to collaborate with periphery complementors and create complementary sub-systems to organize platform IE [73,74]. The interactions among platform actors advance the activities to create and merge multiple kinds of values [75]. Firms may gain more benefits in collective activities aiming to set standards for technological platforms when they have more nondisclosed components which complement their disclosed patents [76]. However, collaborating with complementors does not necessarily bring more gains for the firms, but may trap them in a prisoner's dilemma once the market is saturated [77]. More comprehensively, integrated approaches have been developed and utilized to analyze the configuration of platform IE, such as the 6C (context, cooperation, construct, configuration, capability, and change) framework [5], ecosystem-as-structure perspective [78], and synthesized actor-activity view [79]. Scholars also conceptualized ecosystem-specific advantages (resources, structure, and governance) and developed a framework to manage the collaborations among actors and leverage these advantages for the internationalization of digital platforms [80].

For the latter, studies primarily investigated how to develop platform technologies and products in the IE context. One of the prominent challenges in this process is to 
appropriately balance cooperation and competition. Focal organizations usually need to dynamically govern multilateral cooperative relations with other actors and mitigate potential conflicts by supra dyadic mechanisms [81]. Evidence shows that competitive positions and cooperative motivations of the firms could together shape both the level of individual support and the level of group consensus in collective activities for the creation of technological standards of platforms [82]. Ecosystem strategies, both considering cooperation and competition with different emphases, may be viable to address this tension, such as bottleneck strategy to simultaneously cooperate and compete, component strategy mainly to cooperate, and system strategy chiefly to compete [83]. Additionally, to develop greener products in platform IE, symbiosis strategies (mutualism and predation symbiosis) have been found effective in the emerging market [84].

Moreover, the diffusion of platform technologies and products in ecosystems as a critical issue has also been studied. For instance, software platforms may be diffused among developers through hackathons, and the level of platform diffusion is shaped by the characteristics of hackathons and the experience of the attendees [85]. Over time, complementary developers in the videogame industry may defect from the incumbent firms that introduce a new generation of technology platforms with greater developing challenges and migrate to the rival platforms that are easier to support, which forces these firms to share more knowledge with developers and emphasize internal development more [86]. In addition, the sales of the video games launched at late stages of the life cycle of platforms may be lower than those launched earlier [87]. Finally, scholars also highlighted the significance of institutional complementarities to the creation and diffusion of product platforms [88].

\subsubsection{Stream 3: Regional Development}

Documents in Stream 3 primarily explored innovation in different regions and industries. For innovation at the cluster level, articles revealed the contribution of actors' joint development to cultivate digital industry clusters [89], the uniform effects of regional policies to create biotech clusters in Spain [90], and the IE environmental factors (economic, technological, and market) for the manufacturing cluster in Brazil to develop complementary capabilities [91]. For national industrial innovation, authors found that the government and public organizations have a domain position in governing the evolution of IE [92]. The IE approach was found to be critical to promote the environmental sustainability of regional industries in emerging markets [11,92]. Identifying the collaborative actors and potential stakeholders is also important to industrial innovation [93]. IE at the industry level such as the 3D printing industry in China may be divided into three sub-ecosystems (i.e., science, technology, and business ecosystems) [94], while IE at the country level such as the creation of Society 5.0 may be composed of science, technology, and innovation ecosystems [95]. Additionally, for the transitions towards innovative regions, the economic delta IE has been studied from the industrial system and social network perspectives [96].

Scholars also paid close attention to factors and approaches driving the creation of smart and sustainable cities. For instance, the establishment of smart cities collectively depends on the technological, environmental, and institutional factors in Europe [97]. It is of importance that the actors are aligned to gain shared objectives in value creation and capture activities in the Netherlands [98]. As one of the key actors, universities may play a dominant role as the orchestrator for the creation of innovative cities [99]. To build sustainable cities, the viable approaches include collaborations among actors, experimentation for IE design, and platformization of technological innovation [100].

\subsubsection{Stream 4: IE Conceptualization and Theorization}

Stream 4 provides studies contributing to conceptualizing and theorizing IE. Some scholars focused on distinguishing IE from IE-related concepts, contributing to explicitly conceptualizing this emerging concept. As presented above, the connections between IE and IS [6,20,101], and between IE and BE [24,27,29], have been systematically investigated. 
In addition, the main applications of the ecosystem concept in B2B [3] and management [32] fields have been summarized. Recently, based on these works, scholars have begun to generate contextual and general IE concepts. For instance, Yin et al. defined the "sustainable and smart product IE" concept to explore the development of products characterized by smart and sustainable properties [102], while Jütting introduced the "mission-oriented IE" term to investigate how to address sustainability issues [8]. More comprehensively, Granstrand and Holgersson [23] decoded the main IE definitions from existing literature and conceptualized the IE concept with higher compatibility.

The authors also advance the theorization of IE by structuring and modelling the architecture of ecosystems. From the structuralism perspective, the ecosystem has been constructed by four components: activities (specific actions to realize value propositions), actors (entities to perform activities), positions (locations connecting activities and actors), and links (transfers among actors) [38]. This framework was utilized to generate the Ecosystem Pie Model for the design of ecosystems [103]. In the same line, authors also constructed ecosystems from the perspective of modular complementarities in production and consumption dimensions [30]. From the system perspective, scholars highlighted the complexity and evolvability of ecosystems and treated them as complex adaptive systems [104,105]. From the multi-level view, Walrave et al. [37] proposed a framework for path-breaking innovation emphasizing both the internal alignment and external viability of ecosystems. From the network perspective, Shipilov and Gawer [31] argued that ecosystem research may be extended based on the achievements in the domain of inter-organizational networks. They focused on the modular and complementary components of ecosystems and utilized network approaches (e.g., matrix thinking and link strengths) to advance the development of a Graph Theory to theorize ecosystems. Finally, scholars also summarized the structures of IE [28].

\subsubsection{Stream 5: Entrepreneurship and Innovation}

Most of the studies in Stream 5 investigated entrepreneurship and innovation at the organizational level from an IE perspective. First, university entrepreneurial organizations are playing increasingly important roles and have gained significant academic attention. Evidence shows that dynamic university-industry [106] and industry-university [107] knowledge transfer advances the establishment and growth of university spin-offs. In addition, social capital (in structural, cognitive, and relational dimensions) can be leveraged by business incubators of entrepreneurial universities to cultivate entrepreneurial IE and advance its sustainable development [108]. Second, generally for entrepreneurial firms, public-private interactions driven by regional-specific policies contribute to the success of business models for commercializing new products [2]. Identifying, matching, and bridging novel resources and potential needs can also assist focal firms to work as resource integrators, collaborators, transaction enablers, or bridge providers in digital entrepreneurial activities [109]. Finally, enhancing the absorptive capacities of regional ecosystems may be effective to attract multinational enterprises and then catalyze more entrepreneurial ventures [110].

Articles also examined the challenges and countermeasures for individual entrepreneurs in entrepreneurial and innovative practices in IE environments. Challenged by collective uncertainties in ecosystem entrepreneurial activities, entrepreneurs may deal with this kind of uncertainty through a perceive-bridge-mitigate process [111]. The individual entrepreneur may also encounter discrepant goals and complex opportunities across ecosystem boundaries, which could be addressed by their self-regulatory processes [35]. Moreover, entrepreneurs could leverage the advantages of four kinds of platform-based IE categorized by capabilities in terms of product/service innovation and commercialization in their entrepreneurial processes [112]. Academic entrepreneurs can also utilize the social networks of entrepreneurial universities and the corresponding spin-offs as knowledge intermediaries to gain innovation resources [113].

Table 4 presents the five research streams in detail. 
Table 4. Emerging streams, issues, and studies of IE research.

\begin{tabular}{|c|c|}
\hline $\begin{array}{l}\text { Streams (Number of } \\
\text { Documents) }\end{array}$ & Issues Investigated (Representative Studies) \\
\hline $\begin{array}{c}\text { Technology } \\
\text { innovation (34) }\end{array}$ & $\begin{array}{ll}\text { - } & \text { Creation of technological IE [1,47-53,59]. } \\
\text { - } & \text { Evolution of technological IE [13,54-58]. } \\
\text { - } & \text { Orchestration of technological IE [15,61-63,114]. } \\
\text { - } & \text { Inter-organizational collaborations in technological IE [4,64-68]. } \\
\text { - } & \text { Technological substitutions in IE }[36,60,69] . \\
\text { - } & \text { Technological environments in IE [70,71]. }\end{array}$ \\
\hline Platform IE (32) & $\begin{array}{l}\text { - } \quad \text { Organization of platform IE [5,72-80]. } \\
\text { - } \quad \text { teoperation and competition in developing platform } \\
\text { - } \quad \text { Diffusion of platform technologies and products [85-88]. }\end{array}$ \\
\hline $\begin{array}{c}\text { Regional } \\
\text { development (29) }\end{array}$ & $\begin{array}{ll}\text { - } & \text { Cluster IE [89-91,115]. } \\
\text { - } & \text { National and industrial IE [10,11,92-95]. } \\
\text { - } & \text { Economic delta IE [96]. } \\
\text { - } & \text { Smart and sustainable city IE [97-100,116]. }\end{array}$ \\
\hline $\begin{array}{l}\text { IE conceptualization and } \\
\text { theorization }(27)\end{array}$ & $\begin{array}{ll}\text { - } & \text { IE conceptualization }[3,6,20,23,24,27,29,32,101,102] \text {. } \\
\text { - } & \text { IE theorization }[28,30,31,37,38,103-105] .\end{array}$ \\
\hline $\begin{array}{l}\text { Entrepreneurship and } \\
\quad \text { innovation (14) }\end{array}$ & $\begin{array}{ll}\text { - } & \text { University entrepreneurial organizations }[106-108,117] . \\
\text { - } & \text { Entrepreneurial firms }[2,109,110] . \\
\text { - } & \text { Individual entrepreneurs }[35,111-113] .\end{array}$ \\
\hline
\end{tabular}

\section{Discussion and Future Research}

\subsection{Technology Innovation}

As summarized above, studies in Stream 1 mainly explored how to implement technology innovation in evolutionary and changing IE. Since technology innovation is increasingly challenging in dynamic IE, burgeoning technologies may dim the dominant position of the focal firm, but enhance the roles of other IE actors such as universities, users, and public research institutions in orchestrating the evolution of technological IE. This may be more possible for radical, inclusive, and sustainable technology innovation and product development. For instance, sustainable technology innovations are increasingly challenging and need the collective actions of all stakeholders and the leadership of other IE actors such as public organizations. Moreover, the impacts of interdependent relationships in technology innovation on focal firms' performance have been studied in this line of research, but how focal firms motivate other IE actors to participate in collaborative innovation activities has not received enough attention. Besides, the benefits of collaborations do not exist alone but co-exist with diverse conflicts and contradictions among IE actors. In addition, the changing technological IE is not a closed but an open system, which sometimes is even determined by factors from other systems such as policy, cultural, and academic systems that are overlooked in these articles.

Therefore, ways to extend existing studies in this stream may be the following. For instance, exploring the roles of other IE actors such as universities and small firms, rather than focal large firms in creating and orchestrating IE, could extend existing findings. Distinguishing different types of technological innovation may also complement extant research. Besides, examining the impacts of cognitive and emotional factors on actors decision making can also enrich the limited knowledge on actors' innovation behaviors in IE. The tensions between collaborative benefits and the corresponding drawbacks deserve more extensive investigations. Last but not least, research attention to the roles of nontechnological factors in influencing the dynamics of technological IE is worthy.

\subsection{Platform IE}

Regarding the research in Stream 2, scholarly attention has been paid to the organization of platforms and the development of platform technologies and products. On one 
hand, these studies advance the structural and configurational understanding of platform organizations. They have highlighted the aspects of the complexity of platform IE (e.g., components, evolution, and links) that were mainly conceptually and theoretically discussed but that lacked empirical investigations. Thus, to better understand how to organize and govern platform IE, dynamics- and complexity-related perspectives or approaches may be promising tools for both theoretical and empirical examinations of the organization of platform IE. On the other hand, in this stream, relationship management and platform diffusion are core issues to research new platform technologies and products development. These achievements chiefly extend the understanding of the cooperation, competition, and coopetition of focal organizations with complementary platform components or participants, as well as the diffusion of platforms among component developers and platform users. These studies mainly investigated one kind of digital or software platform that the focal firms or platform leaders leverage to develop platform technologies and products. Challenges raised from these empirical studies may concern whether these findings apply to other kinds of platforms, i.e., the universality of these findings across different platforms, and what are the differences between platform leaders and complementors in managing innovation resources and adapting innovation environments in dynamic IE to develop platform technologies and products. For example, knowledge on how to diffuse sustainable platform products and technologies by different IE actors may be scarce.

Hence, to address these gaps in existing research on platform IE, adopting the evolutionary and complex adaptation system perspectives may be beneficial to unpack how a platform IE evolves and how it can be orchestrated. Among this kind of research, coordinating complementary IE artifacts (e.g., resources and components) and actors across industrial, geographical, and IE boundaries may serve as a fruitful direction to provide insightful findings for theories and practices. Besides, comparative studies on different kinds of platforms may also extend existing findings in this stream. This is the same for research on how different actors (e.g., leaders, followers, and complementors) match their internal and external innovation resources and environments.

\subsection{Regional Development}

Research in Stream 3 advances the literature on different levels of regional and industrial innovation. They mainly revealed the innovation mechanisms in a given level (e.g., cluster, city, or country), leaving the cross-level studies less explored. What is also lacking is exploring the orchestrating tools and mechanisms of regional IE by other actors (e.g., public agents, research institutions, and industrial associations) excepting focal firms. More specifically, these studies extend the research on the creation of smart and sustainable cities by utilizing the IE approach. The findings highlight the importance of collaborative activities and sharing objectives to establish smarter and greener cities. However, knowledge on how to integrate actors and activities in different sub-systems is limited. In addition, how to generate universal indicators and principles from these city-specific findings is also a challenging task for future research.

Thus, this body of research on regional development may be advanced by crossboundary and comparative investigations. For instance, revealing interaction mechanisms across different levels of regional IE could complement existing findings primarily based on single-level research. Studies on different orchestrators in terms of their governing tools and mechanisms may also contribute. Since IE elements from different sub-systems impact each other, studies on how to collectively orchestrate cross-system factors will contribute to systematic findings. More fundamentally, compatible indicators or principles for smart and sustainable regional (city, region, and country) transitions will enable quantitative evaluation and comparison between regions.

\subsection{IE Conceptualization and Theorization}

Studies in Stream 4 provide fruitful achievements for conceptualizing and theorizing IE by review and theoretical works. These articles fundamentally not only distinguish IE 
from other relevant concepts through unpacking their similarities and differences but also advance the theorization of IE by communicating the connection between IE and other closely related theories. These findings extend the understanding of what IE looks like via explicit definitions and how IE could be managed by structural frameworks. This group of studies is among the ones that can most inspire and advance future explorations in the IE field, especially for empirical studies. These studies will also significantly advance future research on sustainability.

Promising research opportunities may be catalyzed by these fundamental and profound theoretical achievements. For instance, these studies (e.g., [23,30,38]) may stimulate more theoretical discussion and empirical examinations of the key elements of IE (actors, activities, relations, artifacts, and evolution). This is also applied to exploiting the findings results from bridging IE and other maturing theories (e.g., [31,104,105]). Additionally, exploring the structural features of IE, especially in terms of the dynamic interaction mechanisms between IE elements, is also one promising direction.

\subsection{Entrepreneurship and Innovation}

Scholars in Stream 5 contribute to the literature on entrepreneurship and innovation. They pay great attention to university entrepreneurial organizations (e.g., university spinoffs and university entrepreneurial incubators), multinational enterprises, and individual entrepreneurs. The investigated entrepreneurial IE is always led by focal firms, keeping other actors or stakeholders (e.g., governments, non-profit institutions, research institutions, and users) located at the periphery of IE and acting as complementors. However, since the activities and outcomes of innovative entrepreneurship are increasingly dependent on the collective actions of diverse partners, it is not necessarily a case of which actor is the most important. Therefore, what is lacking in this stream may be investigation of the collective arrangements of IE at the system level as well as the orchestration of entrepreneurial IE across regions by different actors. Meanwhile, these scholars also highlighted that entrepreneurial challenges arise from multiple aspects of the complexity of entrepreneurial IE such as different kinds of uncertainty, goal, and performance, any of which may determine the processes and outcomes of individual entrepreneurship. These challenges and the corresponding countermeasures for entrepreneurs have not received enough investigation in this stream.

To smooth these gaps, future research could pay more attention to how to motivate diverse IE actors at the system level to advance entrepreneurial innovation and how to orchestrate entrepreneurial IE by different actors. More specifically for individual entrepreneurs, how to cope with complex challenges in evolutionary IE by different tools including cognitive mechanisms is also a challenge for future research. Besides, leveraging sustainable innovation for entrepreneurship and promoting sustainability through entrepreneurship processes are also promising research directions in the IE field.

Based on the identified IE conceptual framework (Table A1) and the discussion of state-of-the-art IE research, Table 5 summarizes the main recommendations for future IE research.

Table 5. Suggestions for future IE research.

\begin{tabular}{|c|c|}
\hline Streams & Suggestions \\
\hline $\begin{array}{l}\text { Technology } \\
\text { innovation }\end{array}$ & $\begin{array}{l}\text { - Study roles of neglected actors (e.g., governments, users, SMEs, and universities) in evolutionary IE } \\
\text { especially for sustainable innovation. } \\
\text { - Consider features of technological innovation (e.g., incremental, radical/disruptive, sustainable, social, } \\
\text { and inclusive) in the orchestration of IE. } \\
\text { - } \quad \text { Explore the influence of cognitive and emotional factors (e.g., over-optimism, willingness, risk } \\
\text { - } \quad \text { Investigate collaborations and conflicts among actors across IE boundaries. } \\
\text { - } \quad \text { Research potential technological and non-technological factors influencing the substitutions of } \\
\text { technologies and firms' adaptations of new technologies in IE. }\end{array}$ \\
\hline
\end{tabular}


Table 5. Cont.

\begin{tabular}{|c|c|}
\hline Streams & Suggestions \\
\hline Platform IE & $\begin{array}{l}\text { - Introduce evolutionary and complex system perspectives to unpack the process of dynamic platform IE } \\
\text { orchestration. } \\
\text { Explore coordinating mechanisms of complementary resources, components, and actors across } \\
\text { industrial, geographical, and IE boundaries to organize platform IE and create different platform } \\
\text { products and technologies such as green and smart products and technologies. } \\
\text { - Study how to diffuse different kinds of platforms (e.g., digital vs. non-digital, tangible vs. intangible, } \\
\text { and sustainable vs. general) across actors and markets by the IE approach. } \\
\text { Reveal how IE actors acting as leaders and complementors match internal and external resources, } \\
\text { capabilities, goals, and environments. }\end{array}$ \\
\hline $\begin{array}{c}\text { Regional } \\
\text { development }\end{array}$ & $\begin{array}{l}\text { - Examine the dynamic development process of regional industry IE across levels (cluster, city, province, } \\
\text { economic delta, country). } \\
\text { - Study how different IE orchestrators govern regional and industrial innovation by specific tools and } \\
\text { mechanisms. } \\
\text { Integrate collective activities among actors embedded in different sub-systems (knowledge, business, } \\
\text { technology, political, academic, cultural, and stakeholder systems) of IE. } \\
\text { Develop compatible indicators, elements, principles, and frameworks for the creation and governance } \\
\text { of smart and sustainable regional IE (city, region, and country) by comparable studies. }\end{array}$ \\
\hline $\begin{array}{l}\text { IE } \\
\text { conceptualization } \\
\text { and theorization }\end{array}$ & $\begin{array}{l}\text { - Apply these IE-related concepts to guide empirical studies, including research on diverse issues to } \\
\text { promote sustainability. } \\
\text { Bridge the IE and other relevant concepts, as well as bridge the emerging IE theory and other maturing } \\
\text { theories. } \\
\text { Employ the key elements of the IE concept (e.g., actors, activities, relations, artifacts, evolution, and the } \\
\text { specific affiliated elements) and their configurations (e.g., different structures, diversified relations, } \\
\text { modularity, alliances, networks) to conduct empirical studies. } \\
\text { Explore the interacting mechanisms between IE elements across evolutionary stages (e.g., cooperation } \\
\text { or complementarity, competition or substitution, coopetition, and symbiosis). }\end{array}$ \\
\hline $\begin{array}{l}\text { Entrepreneurship } \\
\text { and Innovation }\end{array}$ & $\begin{array}{l}\text { - Research how to collectively motivate diverse regional IE actors/stakeholders (e.g., public, private, } \\
\text { market, academic, and governmental organizations) to advance innovative entrepreneurship. } \\
\text { Study how to govern entrepreneurship by different IE actors/orchestrators (e.g., university spin-offs, } \\
\text { public organizations, and non-profit organizations) across regions. } \\
\text { - Reveal individual's cognitive factors in managing complex IE uncertainties and risks, goals and } \\
\text { performance, and technologies and products. } \\
\text { - Unpack the mechanisms that individuals leverage to cope with complex, ever-changing, and collective } \\
\text { IE challenges. } \\
\text { Leverage sustainable innovation for entrepreneurship and promote sustainable innovation in the } \\
\text { process of entrepreneurship in the IE context. }\end{array}$ \\
\hline
\end{tabular}

\section{Conclusions}

This study departs from past reviews on the connections between IE and other related concepts by focusing on IE to unpack the intellectual structure of the research fronts of IE literature and distill corresponding recommendations to progress future IE research. Utilizing a systematic literature review approach, 136 articles representing the core and latest knowledge of the IE literature were identified from the 405 IE studies via a bibliographic coupling technique, and subsequently, emerging research streams of IE literature were detected according to the research focuses of these articles by a content analysis method. Results show that current IE research fronts include five research streams, namely technological innovation, platform IE, regional development, IE conceptualization and theorization, and entrepreneurship and innovation. Through analysis and discussion of these streams, recommendations for future IE research in each stream are offered. Therefore, this review extends past reviews and provides a comprehensive appreciation of the state-of-the-art IE research providing targeted theoretical and practical implications.

This study provides implications for leveraging the IE approach to advance sustainable development. Theoretically, to advance sustainability research in the above five research streams, future research can employ the IE approach (including the five key components 
and corresponding diverse affiliated elements) as operational conceptual and theoretical tools. In practice, to identify and govern the diverse factors shaping the outcomes of sustainability practices in dynamic and interdependent socio-techno-economic environments, enterprise managers, policy makers, non-profit groups, and other stakeholders are more likely to succeed with the help of the IE approach and mindset. To sum up, sustainability research and practice might significantly benefit from utilizing the IE approach.

Author Contributions: Conceptualization, Y.G.; methodology, Y.G.; software, Y.G.; data curation, Y.G.; formal analysis—bibliometric analysis, Y.G. and H.Z.; formal analysis—content analysis, Y.G. and H.Z.; supervision, L.H.; writing—original draft, Y.G. and C.H.; writing—review and editing, L.H. and C.H. All authors have read and agreed to the published version of the manuscript.

Funding: This research received no external funding.

Institutional Review Board Statement: Not applicable.

Informed Consent Statement: Not applicable.

Conflicts of Interest: The author declares no conflict of interest.

\section{Appendix A}

Table A1. Main keywords defining innovation ecosystem.

\begin{tabular}{|c|c|c|c|c|c|c|c|}
\hline \multirow{2}{*}{ Author, Year } & \multirow{2}{*}{$\begin{array}{l}\text { Views Defining } \\
\text { IE }\end{array}$} & \multirow{2}{*}{ TC } & \multicolumn{5}{|c|}{ Keywords and Affiliated Elements } \\
\hline & & & Actors & Activities & Relations & Artifacts & Evolution \\
\hline $\begin{array}{l}\text { Adner, } 2006 \text { [33], } \\
\text { p. } 2\end{array}$ & Arrangements & 568 & Firms, customer & $\begin{array}{l}\text { Combine offerings } \\
\text { into solutions }\end{array}$ & Collaborative & Offerings & \\
\hline $\begin{array}{l}\text { Papaioannou et al., } \\
2009 \text { [34], p. } 326\end{array}$ & $\begin{array}{l}\text { Interrelations } \\
\text { and processes }\end{array}$ & 28 & Individual actors & $\begin{array}{l}\text { Adaptation and } \\
\text { survival }\end{array}$ & Interrelations & & $\begin{array}{c}\text { Evolutionary, } \\
\text { functional } \\
\text { processes }\end{array}$ \\
\hline $\begin{array}{l}\text { Nambisan and } \\
\text { Baron, } 2013 \text { [35], } \\
\text { p. } 1071\end{array}$ & Network & 210 & $\begin{array}{l}\text { Companies and } \\
\text { other entities }\end{array}$ & $\begin{array}{l}\text { Develop new } \\
\text { products and } \\
\text { services }\end{array}$ & $\begin{array}{c}\text { Loosely } \\
\text { interconnected, } \\
\text { cooperatively and } \\
\text { competitively }\end{array}$ & $\begin{array}{l}\text { Technologies, } \\
\text { knowledge, skills, } \\
\text { products, and } \\
\text { services }\end{array}$ & Coevolve \\
\hline $\begin{array}{l}\text { Still et al., } 2014 \\
\text { [118], p. } 246\end{array}$ & Network & 32 & $\begin{array}{l}\text { Organizations, } \\
\text { human networks, } \\
\text { interdependent } \\
\text { firms }\end{array}$ & $\begin{array}{l}\text { Generate creativity } \\
\text { and output, create } \\
\text { and deliver } \\
\text { products and } \\
\text { services, creating } \\
\text { sustained value, } \\
\text { co-creation }\end{array}$ & $\begin{array}{l}\text { Connections, } \\
\text { symbiotic } \\
\text { relationships, a } \\
\text { network of } \\
\text { relationships }\end{array}$ & $\begin{array}{l}\text { Information, talent } \\
\text { and financial } \\
\text { resources, a milieu } \\
\text { conducive to business } \\
\text { growth, products and } \\
\text { services, value }\end{array}$ & Sustainable \\
\hline $\begin{array}{l}\text { Jucevicius et al., } \\
2016 \text { [119], p. } 430\end{array}$ & Network & 8 & $\begin{array}{c}\text { Actors from } \\
\text { industry, } \\
\text { government, and } \\
\text { academia }\end{array}$ & $\begin{array}{l}\text { Innovative } \\
\text { activities and } \\
\text { performance }\end{array}$ & $\begin{array}{l}\text { A complex } \\
\text { network }\end{array}$ & & Interactions \\
\hline $\begin{array}{l}\text { Bomtempo et al., } \\
2017 \text { [120], p. } 221\end{array}$ & Network & 21 & $\begin{array}{l}\text { Innovative actors } \\
\text { (including focal firm, } \\
\text { suppliers, buyers, } \\
\text { and complementors) }\end{array}$ & $\begin{array}{l}\text { Provide products } \\
\text { and services, create } \\
\text { value, diffuse } \\
\text { innovations }\end{array}$ & $\begin{array}{l}\text { Organized into a } \\
\text { network }\end{array}$ & $\begin{array}{l}\text { Products and services, } \\
\text { value, innovations }\end{array}$ & \\
\hline $\begin{array}{l}\text { Ding and Wu, } \\
2018 \text { [10], p. } 2\end{array}$ & Network system & 10 & $\begin{array}{l}\text { Governments, } \\
\text { enterprises, and } \\
\text { customers }\end{array}$ & $\begin{array}{c}\text { Interact, } \\
\text { communicate, or } \\
\text { promote } \\
\text { innovation, create } \\
\text { products }\end{array}$ & $\begin{array}{l}\text { Complementary, } \\
\text { interact, } \\
\text { communicate }\end{array}$ & Innovation, products & \\
\hline $\begin{array}{c}\text { Gomes et al., } \\
2018 \text { [111], p. } 172\end{array}$ & Context & 35 & $\begin{array}{c}\text { Entrepreneur, } \\
\text { complementary } \\
\text { innovators } \\
\text { (including suppliers, } \\
\text { customers, and } \\
\text { other partners) }\end{array}$ & $\begin{array}{c}\text { Create and capture } \\
\text { value }\end{array}$ & Complementary & Context, value & $\begin{array}{l}\text { Different } \\
\text { moments }\end{array}$ \\
\hline $\begin{array}{l}\text { Gomes et al., } \\
2018 \text { [27], p. } 45\end{array}$ & Network & 120 & $\begin{array}{l}\text { Actors (including } \\
\text { focal firm, } \\
\text { customers, } \\
\text { suppliers, } \\
\text { complementary } \\
\text { innovators, and } \\
\text { regulators) }\end{array}$ & Co-creation value & $\begin{array}{l}\text { Interconnected and } \\
\text { interdependent } \\
\text { network, } \\
\text { complementary, } \\
\text { cooperation, and } \\
\text { competition }\end{array}$ & Value & $\begin{array}{c}\text { A lifecycle, a } \\
\text { co-evolution } \\
\text { process }\end{array}$ \\
\hline
\end{tabular}


Table A1. Cont.

\begin{tabular}{|c|c|c|c|c|c|c|c|}
\hline \multirow{2}{*}{ Author, Year } & \multirow{2}{*}{$\begin{array}{c}\text { Views Defining } \\
\text { IE }\end{array}$} & \multirow{2}{*}{ TC } & \multicolumn{5}{|c|}{ Keywords and Affiliated Elements } \\
\hline & & & Actors & Activities & Relations & Artifacts & Evolution \\
\hline $\begin{array}{l}\text { Holgersson et al., } \\
2018 \text { [36], p. } 303\end{array}$ & System & 42 & Actors, firm & $\begin{array}{l}\text { Open innovation } \\
\text { activity, activities }\end{array}$ & $\begin{array}{l}\text { Interconnected, } \\
\text { organizational and } \\
\text { market relations, } \\
\text { institutions }\end{array}$ & Resources & \\
\hline $\begin{array}{l}\text { Mazzucato and } \\
\text { Robinson, } \\
2018 \text { [47], p. } 168\end{array}$ & Network & 21 & $\begin{array}{l}\text { Actors (including } \\
\text { public agencies, } \\
\text { firms, } \\
\text { intermediaries, and } \\
\text { other actors) }\end{array}$ & $\begin{array}{l}\text { Contribute to the } \\
\text { production and use } \\
\text { of a product or } \\
\text { service }\end{array}$ & $\begin{array}{l}\text { Interconnected, } \\
\text { organized around a } \\
\text { particular value } \\
\text { chain/industry }\end{array}$ & A product or service & \\
\hline $\begin{array}{c}\text { Reynolds and } \\
\text { Uygun, } \\
2018 \text { [121], p. } 179\end{array}$ & $\begin{array}{l}\text { Economic } \\
\text { relationships, } \\
\text { systems }\end{array}$ & 36 & $\begin{array}{l}\text { Actors (university } \\
\text { faculty and students, } \\
\text { entrepreneurs, } \\
\text { industry leaders, } \\
\text { government } \\
\text { officials), entities } \\
\text { (market and } \\
\text { non-market } \\
\text { organizations) }\end{array}$ & Enable innovation & $\begin{array}{l}\text { Economic } \\
\text { relationships, } \\
\text { synergistic } \\
\text { relationships }\end{array}$ & $\begin{array}{l}\text { A milieu conducive } \\
\text { to business growth, } \\
\text { knowledge, resources, } \\
\text { internal and external } \\
\text { forces }\end{array}$ & $\begin{array}{l}\text { Dynamic, a } \\
\text { continual } \\
\text { realignment, } \\
\text { changing }\end{array}$ \\
\hline $\begin{array}{c}\text { Russell and } \\
\text { Smorodinskaya, } \\
2018 \text { [105], p. } 115\end{array}$ & Systems & 35 & $\begin{array}{c}\text { Actors, } \\
\text { decision-makers, } \\
\text { entities, and } \\
\text { economies }\end{array}$ & $\begin{array}{l}\text { Enable } \\
\text { self-adaptability to } \\
\text { rapid change }\end{array}$ & $\begin{array}{c}\text { Network } \\
\text { relationships, } \\
\text { collaborative, } \\
\text { non-hierarchic } \\
\text { models, horizontal } \\
\text { linkages }\end{array}$ & $\begin{array}{l}\text { Context (social, } \\
\text { economic, } \\
\text { institutional, etc.), } \\
\text { collaborative } \\
\text { cohesive milieu, } \\
\text { feedback }\end{array}$ & $\begin{array}{l}\text { Changing, } \\
\text { persistent } \\
\text { structural trans- } \\
\text { formations, } \\
\text { continual } \\
\text { networking }\end{array}$ \\
\hline $\begin{array}{l}\text { Schuelke-Leech, } \\
2018 \text { [122], p. } 263\end{array}$ & System & 39 & Agents & Innovation & $\begin{array}{c}\text { Feedback, } \\
\text { interacting with } \\
\text { each other }\end{array}$ & $\begin{array}{c}\text { Feedback and } \\
\text { disturbances, context, } \\
\text { technologies }\end{array}$ & $\begin{array}{l}\text { Dynamic, } \\
\text { adaptive, } \\
\text { progression, } \\
\text { change and } \\
\text { evolve }\end{array}$ \\
\hline $\begin{array}{l}\text { Walrave et al., } \\
2018 \text { [37], p. } 104\end{array}$ & Network & 59 & Actors, end users & $\begin{array}{l}\text { Co-create and } \\
\text { deliver value } \\
\text { proposition, } \\
\text { appropriate the } \\
\text { gains }\end{array}$ & $\begin{array}{l}\text { Interdependent, } \\
\text { complementary }\end{array}$ & $\begin{array}{l}\text { Specialized yet } \\
\text { complementary } \\
\text { resources and/or } \\
\text { capabilities }\end{array}$ & Process \\
\hline $\begin{array}{c}\text { Witte et al., } \\
2018 \text { [123], p. } 226\end{array}$ & $\begin{array}{l}\text { Participants and } \\
\text { resources }\end{array}$ & 17 & Participants & $\begin{array}{l}\text { Contribute to } \\
\text { innovation }\end{array}$ & & Resources & Ongoing \\
\hline $\begin{array}{c}\text { Wu et al., } \\
2018 \text { [106], p. } 224\end{array}$ & System & 11 & $\begin{array}{l}\text { Actors and } \\
\text { organization, } \\
\text { customer }\end{array}$ & $\begin{array}{c}\text { Promote } \\
\text { interaction and } \\
\text { communication, } \\
\text { enable technology } \\
\text { development, } \\
\text { inspire innovation, } \\
\text { innovation } \\
\text { activities }\end{array}$ & $\begin{array}{l}\text { Interaction, } \\
\text { cooperative }\end{array}$ & $\begin{array}{l}\text { Technology, } \\
\text { innovation }\end{array}$ & $\begin{array}{l}\text { Long-term or } \\
\text { temporary, } \\
\text { development }\end{array}$ \\
\hline $\begin{array}{c}\text { Xu et al., } \\
2018 \text { [94], p. } 211\end{array}$ & System & 51 & $\begin{array}{c}\text { Researchers, } \\
\text { university, } \\
\text { enterprises, } \\
\text { outsourcing } \\
\text { partners, technology } \\
\text { providers, and } \\
\text { complementary } \\
\text { product makers }\end{array}$ & $\begin{array}{c}\text { Generates/produces } \\
\text { knowledge, } \\
\text { advances } \\
\text { technological } \\
\text { development, } \\
\text { develops products } \\
\text { and services, } \\
\text { realizes value } \\
\text { propositions }\end{array}$ & $\begin{array}{l}\text { Interconnected, } \\
\text { complementary, } \\
\text { and synergistic }\end{array}$ & $\begin{array}{c}\text { Scientific and } \\
\text { industrial knowledge, } \\
\text { products, and } \\
\text { services }\end{array}$ & Development \\
\hline $\begin{array}{c}\text { Ding et al., } \\
2019 \text { [84], p. } 1565\end{array}$ & System, network & 5 & $\begin{array}{c}\text { Innovation } \\
\text { organizations }\end{array}$ & $\begin{array}{l}\text { Promote } \\
\text { interaction, } \\
\text { communication, } \\
\text { and innovation }\end{array}$ & & $\begin{array}{l}\text { Ecological } \\
\text { environment, } \\
\text { innovation }\end{array}$ & $\begin{array}{l}\text { Long-term or } \\
\text { temporary }\end{array}$ \\
\hline $\begin{array}{c}\text { Gao et al., } \\
2019 \text { [70], p. } 242\end{array}$ & Network & 3 & $\begin{array}{l}\text { Organizations, focal } \\
\text { firm, related } \\
\text { providers }\end{array}$ & $\begin{array}{l}\text { Value creation and } \\
\text { appropriation } \\
\text { through innovation }\end{array}$ & $\begin{array}{l}\text { Interconnected, } \\
\text { complementary }\end{array}$ & $\begin{array}{l}\text { Technologies and } \\
\text { assets }\end{array}$ & \\
\hline $\begin{array}{c}\text { Boyer, } 2020[115], \\
\text { p. } 1\end{array}$ & System & 9 & $\begin{array}{l}\text { Heterogeneous } \\
\text { actors }\end{array}$ & $\begin{array}{l}\text { Perform activities, } \\
\text { play roles, } \\
\text { contribute to the } \\
\text { development of } \\
\text { innovation } \\
\text { processes or } \\
\text { technologies }\end{array}$ & $\begin{array}{l}\text { Complex } \\
\text { relationships }\end{array}$ & $\begin{array}{l}\text { Motivations and } \\
\text { capabilities }\end{array}$ & $\begin{array}{l}\text { Dynamic and } \\
\text { adaptive, } \\
\text { development, } \\
\text { processes }\end{array}$ \\
\hline $\begin{array}{l}\text { Granstrand and } \\
\text { Holgersson, } \\
2020 \text { [23], p. } 3\end{array}$ & System & 71 & Actors & Activities & $\begin{array}{c}\text { Relations } \\
\text { (complementary } \\
\text { and substitute), } \\
\text { institutions }\end{array}$ & Artifacts & Evolving \\
\hline
\end{tabular}




\section{References}

1. Rohrbeck, R.; Holzle, K.; Gemunden, H.G. Opening up for competitive advantage-How Deutsche Telekom creates an open innovation ecosystem. $R$ D Manag. 2009, 39, 420-430. [CrossRef]

2. Li, J.F.; Garnsey, E. Policy-driven ecosystems for new vaccine development. Technovation 2014, 34, 762-772. [CrossRef]

3. Aarikka-Stenroos, L.; Ritala, P. Network management in the era of ecosystems: Systematic review and management framework. Ind. Mark. Manag. 2017, 67, 23-36. [CrossRef]

4. Xie, X.M.; Wang, H.W. How can open innovation ecosystem modes push product innovation forward? An fsQCA analysis. J. Bus. Res. 2020, 108, 29-41. [CrossRef]

5. Rong, K.; Hu, G.Y.; Lin, Y.; Shi, Y.J.; Guo, L. Understanding business ecosystem using a 6C framework in Internet-of-Things-based sectors. Int. J. Prod. Econ. 2015, 159, 41-55. [CrossRef]

6. Bassis, N.F.; Armellini, F. Systems of innovation and innovation ecosystems: A literature review in search of complementarities. J. Evol. Econ. 2018, 28, 1053-1080. [CrossRef]

7. Costa, J.; Matias, J.C.O. Open innovation 4.0 as an enhancer of sustainable innovation ecosystems. Sustainability 2020, $12,8112$. [CrossRef]

8. Jütting, M. Exploring mission-oriented innovation ecosystems for sustainability: Towards a literature-based typology. Sustainability 2020, 12, 6677. [CrossRef]

9. Tolstykh, T.; Gamidullaeva, L.; Shmeleva, N.; Lapygin, Y. Regional development in Russia: An ecosystem approach to territorial sustainability assessment. Sustainability 2020, 12, 6424. [CrossRef]

10. Ding, L.; Wu, J.X. Innovation ecosystem of CNG vehicles: A case study of its cultivation and characteristics in Sichuan, China. Sustainability 2018, 10, 39. [CrossRef]

11. Wu, J.L.; Yang, Z.J.; Hu, X.B.; Wang, H.Q.; Huang, J. Exploring driving forces of sustainable development of China's new energy vehicle industry: An analysis from the perspective of an innovation ecosystem. Sustainability 2018, 10, 4827. [CrossRef]

12. Grosse, M. How user-innovators pave the way for a sustainable energy future: A study among German energy enthusiasts. Sustainability 2018, 10, 4836. [CrossRef]

13. Cao, X.; Ouyang, T.H.; Balozian, P.; Zhang, S.X. The role of managerial cognitive capability in developing a sustainable innovation ecosystem: A case study of Xiaomi. Sustainability 2020, 12, 7176. [CrossRef]

14. Hu, J.B.; Ouyang, T.H.; Wei, W.X.; Cai, J.W. How do manufacturing enterprises construct e-commerce platforms for sustainable development? A case study of resource orchestration. Sustainability 2020, 12, 6640. [CrossRef]

15. Hsieh, Y.C.; Lin, K.Y.; Lu, C.; Rong, K. Governing a sustainable business ecosystem in Taiwan's circular economy: The story of Spring Pool Glass. Sustainability 2017, 9, 1068. [CrossRef]

16. Chaminade, C.; Randelli, F. The role of territorially embedded innovation ecosystems accelerating sustainability transformations: A case study of the transformation to organic wine production in Tuscany (Italy). Sustainability 2020, 12, 4621. [CrossRef]

17. Konietzko, J.; Bocken, N.; Hultink, E.J. A tool to analyze, ideate and develop circular innovation ecosystems. Sustainability 2020, 12, 417. [CrossRef]

18. Barbulescu, O.; Constantin, C.P. Sustainable growth approaches: Quadruple helix approach for turning Brasov into a startup city. Sustainability 2019, 11, 6154. [CrossRef]

19. Sammut, N.; Spiteri, D.; Sammut, J.P.; Coppola, I.; Lepre, R.; Lebrun, B. The status of sustainable social innovation in Malta. Sustainability 2020, 12, 4238. [CrossRef]

20. Suominen, A.; Seppanen, M.; Dedehayir, O. A bibliometric review on innovation systems and ecosystems: A research agenda. Eur. J. Innov. Manag. 2019, 22, 335-360. [CrossRef]

21. Dedehayir, O.; Makinen, S.J.; Ortt, J.R. Roles during innovation ecosystem genesis: A literature review. Technol. Forecast. Soc. Chang. 2018, 136, 18-29. [CrossRef]

22. Oh, D.S.; Phillips, F.; Park, S.; Lee, E. Innovation ecosystems: A critical examination. Technovation 2016, 54, 1-6. [CrossRef]

23. Granstrand, O.; Holgersson, M. Innovation ecosystems: A conceptual review and a new definition. Technovation 2020, 90-91, 1-12. [CrossRef]

24. Gupta, R.; Mejia, C.; Kajikawa, Y. Business, innovation and digital ecosystems landscape survey and knowledge cross sharing. Technol. Forecast. Soc. Chang. 2019, 147, 100-109. [CrossRef]

25. Thomas, L.; Autio, E. Innovation ecosystems in management: An organizing typology. In Oxford Research Encyclopedia of Business and Management; Oxford University Press: Oxford, UK, 2020.

26. Russo-Spena, T.; Tregua, M.; Bifulco, F. Searching through the jungle of innovation conceptualisations: System, network and ecosystem perspectives. J. Serv. Theory Pract. 2017, 27, 977-1005. [CrossRef]

27. Gomes, L.A.D.; Facin, A.L.F.; Salerno, M.S.; Ikenami, R.K. Unpacking the innovation ecosystem construct: Evolution, gaps and trends. Technol. Forecast. Soc. Chang. 2018, 136, 30-48. [CrossRef]

28. Tomas, D.S.; Bermejo, P.H.D.; Moreira, M.F.; de Souza, W.V.B. The structure of an innovation ecosystem: Foundations for future research. Manag. Decis. 2020, 58, 2725-2742.

29. Hakala, H.; O'Shea, G.; Farny, S.; Luoto, S. Re-storying the business, innovation and entrepreneurial ecosystem concepts: The model-narrative review method. Int. J. Manag. Rev. 2020, 22, 10-32. [CrossRef]

30. Jacobides, M.G.; Cennamo, C.; Gawer, A. Towards a theory of ecosystems. Strateg. Manag. J. 2018, 39, 2255-2276. [CrossRef] 
31. Shipilov, A.; Gawer, A. Integrating research on interorganizational networks and ecosystems. Acad. Manag. Ann. 2020, 14, 92-121. [CrossRef]

32. Tsujimoto, M.; Kajikawa, Y.; Tomita, J.; Matsumoto, Y. A review of the ecosystem concept-Towards coherent ecosystem design. Technol. Forecast. Soc. Chang. 2018, 136, 49-58. [CrossRef]

33. Adner, R. Match your innovation strategy to your innovation ecosystem. Harv. Bus. Rev. 2006, 84, 98-107. [PubMed]

34. Papaioannou, T.; Wield, D.; Chataway, J. Knowledge ecologies and ecosystems? An empirically grounded reflection on recent developments in innovation systems theory. Environ. Plan. C-Gov. Policy 2009, 27, 319-339. [CrossRef]

35. Nambisan, S.; Baron, R.A. Entrepreneurship in innovation ecosystems: Entrepreneurs' self-regulatory processes and their implications for new venture success. Entrep. Theory Pract. 2013, 37, 1071-1097. [CrossRef]

36. Holgersson, M.; Granstrand, O.; Bogers, M. The evolution of intellectual property strategy in innovation ecosystems: Uncovering complementary and substitute appropriability regimes. Long Range Plan. 2018, 51, 303-319. [CrossRef]

37. Walrave, B.; Talmar, M.; Podoynitsyna, K.S.; Romme, A.G.L.; Verbong, G.P.J. A multi-level perspective on innovation ecosystems for path-breaking innovation. Technol. Forecast. Soc. Chang. 2018, 136, 103-113. [CrossRef]

38. Adner, R. Ecosystem as structure: An actionable construct for strategy. J. Manag. 2017, 43, 39-58. [CrossRef]

39. Zhang, C.; Guan, J.C. How to identify metaknowledge trends and features in a certain research field? Evidences from innovation and entrepreneurial ecosystem. Scientometrics 2017, 113, 1177-1197. [CrossRef]

40. Amitrano, C.C.; Tregua, M.; Spena, T.R.; Bifulco, F. On Technology in innovation systems and innovation-ecosystem perspectives: A cross-linking analysis. Sustainability 2018, 10, 3744. [CrossRef]

41. Wang, P. Connecting the parts with the whole: Toward an information ecology theory of digital innovation ecosystems. MIS $Q$. 2021, 45, 397-422. [CrossRef]

42. Danese, P.; Manfe, V.; Romano, P. A systematic literature review on recent lean research: State-of-the-art and future directions. Int J. Manag. Rev. 2018, 20, 579-605. [CrossRef]

43. Agostini, L.; Nosella, A. Inter-organizational relationships involving SMEs: A bibliographic investigation into the state of the art. Long Range Plan. 2019, 52, 1-31. [CrossRef]

44. Zupic, I.; Cater, T. Bibliometric methods in management and organization. Organ. Res. Methods 2015, 18, 429-472. [CrossRef]

45. van Eck, N.J.; Waltman, L. Software survey: VOSviewer, a computer program for bibliometric mapping. Scientometrics 2010, 84, 523-538. [CrossRef]

46. Mrvar, A.; Batagelj, V. Analysis and visualization of large networks with program package Pajek. Complex Adapt. Syst. Modeling 2016, 4, 1-6. [CrossRef]

47. Mazzucato, M.; Robinson, D.K.R. Co-creating and directing innovation ecosystems? NASA's changing approach to public-private partnerships in low-earth orbit. Technol. Forecast. Soc. Chang. 2018, 136, 166-177. [CrossRef]

48. Sun, C.; Wei, J. Digging deep into the enterprise innovation ecosystem How do enterprises build and coordinate innovation ecosystem at firm level. Chin. Manag. Stud. 2019, 13, 820-839. [CrossRef]

49. Gupta, R.; Mejia, C.; Gianchandani, Y.; Kajikawa, Y. Analysis on formation of emerging business ecosystems from deals activities of global electric vehicles hub firms. Energy Policy 2020, 145, 1-13. [CrossRef]

50. Kukk, P.; Moors, E.H.M.; Hekkert, M.P. The complexities in system building strategies-The case of personalized cancer medicines in England. Technol. Forecast. Soc. Chang. 2015, 98, 47-59. [CrossRef]

51. Dattee, B.; Alexy, O.; Autio, E. Maneuvering in poor visibility: How firms play the ecosystem game when uncertainty is high Acad. Manag. J. 2018, 61, 466-498. [CrossRef]

52. Ben Mahmoud-Jouini, S.; Charue-Duboc, F. Experimentations in emerging innovation ecosystems: Specificities and roles. The case of the hydrogen energy fuel cell. Int. J. Technol. Manag. 2017, 75, 28-54. [CrossRef]

53. Jarvi, K.; Almpanopoulou, A.; Ritala, P. Organization of knowledge ecosystems: Prefigurative and partial forms. Res. Policy 2018, 47, 1523-1537. [CrossRef]

54. Ritala, P.; Agouridas, V.; Assimakopoulos, D.; Gies, O. Value creation and capture mechanisms in innovation ecosystems: A comparative case study. Int. J. Technol. Manag. 2013, 63, 244-267. [CrossRef]

55. Randhawa, K.; West, J.; Skellern, K.; Josserand, E. Evolving a value chain to an open innovation ecosystem: Cognitive engagement of stakeholders in customizing medical implants. Calif. Manag. Rev. 2020, 63, 101-134. [CrossRef]

56. Luo, J.X. Architecture and evolvability of innovation ecosystems. Technol. Forecast. Soc. Chang. 2018, 136, 132-144. [CrossRef]

57. Chen, J.; Liu, X.L.; Hu, Y.M. Establishing a CoPs-based innovation ecosystem to enhance competence-the case of CGN in China. Int. J. Technol. Manag. 2016, 72, 144-170.

58. Feng, N.P.; Fu, C.; Wei, F.F.; Peng, Z.L.; Zhang, Q.; Zhang, K.H. The key role of dynamic capabilities in the evolutionary process for a startup to develop into an innovation ecosystem leader: An indepth case study. J. Eng. Technol. Manag. 2019, 54, 81-96. [CrossRef]

59. Jiang, S.M.; Hu, Y.M.; Wang, Z.Y. Core firm based view on the mechanism of constructing an enterprise innovation ecosystem: A case study of Haier Group. Sustainability 2019, 11, 3108. [CrossRef]

60. Huang, J.; Wang, H.Q.; Wu, J.L.; Yang, Z.J.; Hu, X.B.; Bao, M.M. Exploring the key driving forces of the sustainable intergenerational evolution of the industrial alliance innovation ecosystem: Evidence from a case study of China's TDIA. Sustainability 2020, 12, 1320. [CrossRef] 
61. Alexy, O.; George, G.; Salter, A.J. Cui bono? The selective revealing of knowledge and its implications for innovative activity. Acad. Manag. Rev. 2013, 38, 270-291. [CrossRef]

62. Azzam, J.E.; Ayerbe, C.; Dang, R. Using patents to orchestrate ecosystem stability: The case of a French aerospace company. Int. J. Technol. Manag. 2017, 75, 97-120. [CrossRef]

63. Bacon, E.; Williams, M.D.; Davies, G.H. Recipes for success: Conditions for knowledge transfer across open innovation ecosystems. Int. J. Inf. Manag. 2019, 49, 377-387. [CrossRef]

64. Knockaert, M.; Deschryvere, M.; Lecluyse, L. The relationship between organizational interdependence and additionality obtained from innovation ecosystem participation. Sci. Public Policy 2019, 46, 490-503. [CrossRef]

65. Baloutsos, S.; Karagiannaki, A.; Pramatari, K. Identifying contradictions in an incumbent-startup ecosystem-an activity theory approach. Eur. J. Innov. Manag. 2020. [CrossRef]

66. Adner, R.; Kapoor, R. Value creation in innovation ecosystems: How the structure of technological interdependence affects firm performance in new technology generations. Strateg. Manag. J. 2010, 31, 306-333. [CrossRef]

67. Mei, L.; Zhang, T.; Chen, J. Exploring the effects of inter-firm linkages on SMEs' open innovation from an ecosystem perspective: An empirical study of Chinese manufacturing SMEs. Technol. Forecast. Soc. Chang. 2019, 144, 118-128. [CrossRef]

68. Adner, R.; Feller, D. Interdependence, perception, and investment choices: An experimental approach to decision making in innovation ecosystems. Organ Sci. 2019, 30, 109-125. [CrossRef]

69. Adner, R.; Kapoor, R. Innovation ecosystems and the pace of substitution: Re-examining technology S-curves. Strateg. Manag. J. 2016, 37, 625-648. [CrossRef]

70. Gao, Y.C.; Liu, X.L.; Ma, X.M. How do firms meet the challenge of technological change by redesigning innovation ecosystem? A case study of IBM. Int. J. Technol. Manag. 2019, 80, 241-265. [CrossRef]

71. Eggers, J.P.; Park, K.F. Incumbent adaptation to technological change: The past, present, and future of research on heterogeneous incumbent response. Acad. Manag. Ann. 2018, 12, 357-389. [CrossRef]

72. Gawer, A. Bridging differing perspectives on technological platforms: Toward an integrative framework. Res. Policy 2014, 43, 1239-1249. [CrossRef]

73. Wei, F.F.; Feng, N.P.; Yang, S.L.; Zhao, Q.N. A conceptual framework of two-stage partner selection in platform-based innovation ecosystems for servitization. J. Clean Prod. 2020, 262, 1-16. [CrossRef]

74. Kwak, K.; Kim, W.; Park, K. Complementary multiplatforms in the growing innovation ecosystem: Evidence from 3D printing technology. Technol. Forecast. Soc. Chang. 2018, 136, 192-207. [CrossRef]

75. Suseno, Y.; Laurell, C.; Sick, N. Assessing value creation in digital innovation ecosystems: A social media analytics approach. J. Strateg. Inf. Syst. 2018, 27, 335-349. [CrossRef]

76. Miller, C.D.; Toh, P.K. Complementary components and returns from coordination within ecosystems via standard setting. Strateg. Manag. J. 2020. [CrossRef]

77. Mantovani, A.; Ruiz-Aliseda, F. Equilibrium innovation ecosystems: The dark side of collaborating with complementors. Manag. Sci. 2016, 62, 534-549. [CrossRef]

78. Sun, Q.; Wang, C.; Zuo, L.S.; Lu, F.H. Digital empowerment in a WEEE collection business ecosystem: A comparative study of two typical cases in China. J. Clean Prod. 2018, 184, 414-422. [CrossRef]

79. Hou, H.; Cui, Z.Y.; Shi, Y.J. Learning club, home court, and magnetic field: Facilitating business model portfolio extension with a multi-faceted corporate ecosystem. Long Range Plan. 2020, 53, 1-21. [CrossRef]

80. Li, J.T.; Chen, L.; Yi, J.T.; Mao, J.Y.; Liao, J.W. Ecosystem-specific advantages in international digital commerce. J. Int. Bus. Stud. 2019, 50, 1448-1463. [CrossRef]

81. Davis, J.P. The group dynamics of interorganizational relationships: Collaborating with multiple partners in innovation ecosystems. Adm. Sci. Q. 2016, 61, 621-661. [CrossRef]

82. Ranganathan, R.; Ghosh, A.; Rosenkopf, L. Competition-cooperation interplay during multifirm technology coordination: The effect of firm heterogeneity on conflict and consensus in a technology standards organization. Strateg. Manag. J. 2018, 39, 3193-3221. [CrossRef]

83. Hannah, D.P.; Eisenhardt, K.M. How firms navigate cooperation and competition in nascent ecosystems. Strate. Manag. J. 2018, 39, 3163-3192. [CrossRef]

84. Ding, L.; Ye, R.M.; Wu, J.X. Platform strategies for innovation ecosystem: Double-case study of Chinese automobile manufactures. J. Clean Prod. 2019, 209, 1564-1577. [CrossRef]

85. Fang, T.P.; Wu, A.; Clough, D.R. Platform diffusion at temporary gatherings: Social coordination and ecosystem emergence. Strate. Manag. J. 2020, 42, 233-272. [CrossRef]

86. Ozalp, H.; Cennamo, C.; Gawer, A. Disruption in platform-based ecosystems. J. Manag. Stud. 2018, 55, 1203-1241. [CrossRef]

87. Rietveld, J.; Eggers, J.P. Demand heterogeneity in platform markets: Implications for complementors. Organ. Sci. 2018, 29, 304-322. [CrossRef]

88. Helveston, J.P.; Wang, Y.M.; Karplus, V.J.; Fuchs, E.R.H. Institutional complementarities: The origins of experimentation in China's plug-in electric vehicle industry. Res. Policy 2019, 48, 206-222. [CrossRef]

89. Benitez, G.B.; Ayala, N.F.; Frank, A.G. Industry 4.0 innovation ecosystems: An evolutionary perspective on value cocreation. Int. J. Product. Econ. 2020, 228, 1-13. [CrossRef] 
90. Vlaisavljevic, V.; Medina, C.C.; Van Looy, B. The role of policies and the contribution of cluster agency in the development of biotech open innovation ecosystem. Technol. Forecast. Soc. Chang. 2020, 155, 1-15. [CrossRef]

91. Kahle, J.H.; Marcon, E.; Ghezzi, A.; Frank, A.G. Smart products value creation in SMEs innovation ecosystems. Technol. Forecast. Soc. Chang. 2020, 156, 1-14. [CrossRef]

92. Parente, R.; Melo, M.; Andrews, D.; Kumaraswamy, A.; Vasconcelos, F. Public sector organizations and agricultural catch-up dilemma in emerging markets: The orchestrating role of Embrapa in Brazil. J. Int. Bus. Stud. 2020, 52, 647-670. [CrossRef]

93. Pekkarinen, S.; Tuisku, O.; Hennala, L.; Melkas, H. Robotics in Finnish welfare services: Dynamics in an emerging innovation ecosystem. Eur. Plan. Stud. 2020, 28, 1513-1533. [CrossRef]

94. Xu, G.N.; Wu, Y.C.; Minshall, T.; Zhou, Y. Exploring innovation ecosystems across science, technology, and business: A case of 3D printing in China. Technol. Forecast. Soc. Chang. 2018, 136, 208-221. [CrossRef]

95. Fukuda, K. Science, technology and innovation ecosystem transformation toward society 5.0. Int. J. Product. Econ. 2020, 220, 1-14. [CrossRef]

96. Rong, K.; Lin, Y.; Yu, J.; Zhang, Y.; Radziwon, A. Exploring regional innovation ecosystems: An empirical study in China. Ind. Innov. 2020, 28, 1-25. [CrossRef]

97. Camboim, G.F.; Zawislak, P.A.; Pufal, N.A. Driving elements to make cities smarter: Evidences from European projects. Technol. Forecast. Soc. Chang. 2019, 142, 154-167. [CrossRef]

98. Oomens, I.M.F.; Sadowski, B.M. The importance of internal alignment in smart city initiatives: An ecosystem approach. Telecommun. Policy 2019, 43, 485-500. [CrossRef]

99. Thomas, E.; Faccin, K.; Asheim, B.T. Universities as orchestrators of the development of regional innovation ecosystems in emerging economies. Growth. Chang. 2021, 52, 770-789. [CrossRef]

100. Konietzko, J.; Bocken, N.; Hultink, E.J. Circular ecosystem innovation: An initial set of principles. J. Clean Prod. 2020, $253,1-15$. [CrossRef]

101. Ritala, P.; Almpanopoulou, A. In defense of 'eco' in innovation ecosystem. Technovation 2017, 60-61, 39-42. [CrossRef]

102. Yin, D.; Ming, X.G.; Zhang, X.Y. Sustainable and smart product innovation ecosystem: An integrative status review and future perspectives. J. Clean Prod. 2020, 274, 1-19. [CrossRef]

103. Talmar, M.; Walrave, B.; Podoynitsyna, K.S.; Holmstrom, J.; Romme, A.G.L. Mapping, analyzing and designing innovation ecosystems: The ecosystem pie model. Long Range Plan. 2020, 53, 1-9. [CrossRef]

104. Phillips, M.A.; Ritala, P. A complex adaptive systems agenda for ecosystem research methodology. Technol. Forecast. Soc. Chang. 2019, 148, 1-13. [CrossRef]

105. Russell, M.G.; Smorodinskaya, N.V. Leveraging complexity for ecosystemic innovation. Technol. Forecast. Soc. Chang. 2018, 136, 114-131. [CrossRef]

106. Wu, J.X.; Ye, R.; Ding, L.; Lu, C.; Euwema, M. From "transplant with the soil" toward the establishment of the innovation ecosystem: A case study of a leading high-tech company in China. Technol. Forecast. Soc. Chang. 2018, 136, 222-234. [CrossRef]

107. Meng, D.H.; Li, X.J.; Rong, K. Industry-to-university knowledge transfer in ecosystem-based academic entrepreneurship: Case study of automotive dynamics \& control group in Tsinghua University. Technol. Forecast. Soc. Chang. 2019, 141, 249-262.

108. Theodoraki, C.; Messeghem, K.; Rice, M.P. A social capital approach to the development of sustainable entrepreneurial ecosystems: An explorative study. Small Bus. Econ. Group 2018, 51, 153-170. [CrossRef]

109. Amit, R.; Han, X. Value creation through novel resource configurations in a digitally enabled world. Strateg. Entrep. J. 2017, 11, 228-242. [CrossRef]

110. Bhawe, N.; Zahra, S.A. Inducing heterogeneity in local entrepreneurial ecosystems: The role of MNEs. Small Bus. Econ. Group 2019, 52, 437-454. [CrossRef]

111. Gomes, L.A.D.; Salerno, M.S.; Phaal, R.; Probert, D.R. How entrepreneurs manage collective uncertainties in innovation ecosystems. Technol. Forecast. Soc. Chang. 2018, 128, 164-185. [CrossRef]

112. Hsieh, Y.J.; Wu, Y.J. Entrepreneurship through the platform strategy in the digital era: Insights and research opportunities. Comput. Hum. Behav. 2019, 95, 315-323. [CrossRef]

113. Hayter, C.S. A trajectory of early-stage spinoff success: The role of knowledge intermediaries within an entrepreneurial university ecosystem. Small Bus. Econ. Group 2016, 47, 633-656. [CrossRef]

114. Yang, T.K.; Yan, M.R. Exploring the enablers of strategic orientation for technology-driven business innovation ecosystems. Sustainability 2019, 11, 5779. [CrossRef]

115. Boyer, J. Toward an evolutionary and sustainability perspective of the innovation ecosystem: Revisiting the Panarchy Model. Sustainability 2020, 12, 3232. [CrossRef]

116. Helman, J. Analysis of the local innovation and entrepreneurial system structure towards the 'Wroclaw innovation ecosystem' concept development. Sustainability 2020, 12, 10086. [CrossRef]

117. Feng, Y.H.; Wu, J.X.; He, P. Global M\&A and the development of the IC industry ecosystem in china: What can we learn from the case of Tsinghua Unigroup? Sustainability 2019, 11, 106.

118. Still, K.; Huhtamaki, J.; Russell, M.G.; Rubens, N. Insights for orchestrating innovation ecosystems: The case of EIT ICT Labs and data-driven network visualisations. Int. J. Technol. Manag. 2014, 66, 243-265. [CrossRef]

119. Jucevicius, G.; Juceviciene, R.; Gaidelys, V.; Kalman, A. The emerging innovation ecosystems and "Valley of Death": Towards the combination of entrepreneurial and institutional approaches. Inz. Ekon. 2016, 27, 430-438. [CrossRef] 
120. Bomtempo, J.V.; Alves, F.C.; Oroski, F.D. Developing new platform chemicals: What is required for a new bio-based molecule to become a platform chemical in the bioeconomy? Faraday Discuss. 2017, 202, 213-225. [CrossRef] [PubMed]

121. Reynolds, E.B.; Uygun, Y. Strengthening advanced manufacturing innovation ecosystems: The case of Massachusetts. Technol. Forecast. Soc. Chang. 2018, 136, 178-191. [CrossRef]

122. Schuelke-Leech, B.A. A model for understanding the orders of magnitude of disruptive technologies. Technol. Forecast. Soc. Chang. 2018, 129, 261-274. [CrossRef]

123. Witte, P.; Slack, B.; Keesman, M.; Jugie, J.H.; Wiegmans, B. Facilitating start-ups in port-city innovation ecosystems: A case study of Montreal and Rotterdam. J. Transp. Geogr. 2018, 71, 224-234. [CrossRef] 